\title{
Kształtowanie przestrzeni - sprawny system czy chaos? Miejscowy plan zagospodarowania przestrzennego - zakres stanowienia
}

\author{
Anna Wieczorek
}

\section{STRESZCZENIE}

Prawo, to jeden z czynników wpływających w istotny sposób na jakość przestrzeni. Artykuł jest kolejnym z serii artykułów o systemie kształtowania przestrzeni w Polsce i pierwszym z trzech dotyczących zakresu stanowienia miejscowych planów zagospodarowania przestrzennego. W sposób ogólny odnosi się do całości tego zakresu. Dwa kolejne artykuły:

- Ksztattowanie przestrzeni - sprawny system czy chaos? Miejscowy plan zagospodarowania przestrzennego - przeznaczenie terenów;

- Kształtowanie przestrzeni - sprawny system czy chaos? Miejscowy plan zagospodarowania przestrzennego - parametry zabudowy odnoszą się w sposób szczegółowy do kluczowych zagadnień tego zakresu.

W celu zachowania precyzji wypowiedzi posłużono się szeregiem cytatów.

Miejscowy planu zagospodarowania przestrzennego, kluczowy dla kształtowania przestrzeni akt prawa miejscowego, ma wieloznaczny, mało precyzyjny zakres stanowienia, ponieważ:

- $\quad$ zawiera szereg powtórzeń i jest mieszaniną tego, co należy ustalić z wytycznymi i informacjami o uwarunkowaniach, z których ustalenia powinny wynikać,

- $\quad$ w ustawie o planowaniu i zagospodarowaniu przestrzennym i wydanych na jej podstawie przepisach wykonawczych brakuje definicji użytych w nim pojęć oraz jest wiele określeń bliskoznacznych,

- chaos pogłębia niezrozumiały podział na zakres obowiązkowy i zakres fakultatywny.

Wszystko to utrudnia sporządzanie planów miejscowych, a tym samym negatywnie wpływa na jakość przestrzeni oraz prowadzi do niepotrzebnych sporów, w tym sądowych, których dałoby się uniknąc mając precyzyjne prawo.

Słowa kluczowe: miejscowy plan zagospodarowana przestrzennego, zakres stanowienia, przeznaczenie terenu, zagospodarowanie terenu 


\section{Wprowadzenie}

Kluczowy wpływ na kształtowanie przestrzeni ma ustawa o planowaniu i zagospodarowaniu przestrzennym (upzp), na podstawie której sporządza się studia uwarunkowań i kierunków zagospodarowania przestrzennego gmin oraz miejscowe plany zagospodarowania przestrzennego (ryc. 1).

Miejscowy plan zagospodarowania przestrzennego, w skrócie plan miejscowy jest źródłem prawa i aktem prawa miejscowego w rozumieniu art. 87 ust. 2 i art. 94 Konstytucji. Szczególny rodzaj planu miejscowego, to miejscowy plan rewitalizacji [art. 37f ust. 2 upzp].

Prawo nie nakazuje sporządzania planu miejscowego dla terenu całej gminy, sporządza się go obowiązkowo, jeżeli wymagaja tego przepisy odrębne [art. 14 ust. 7 upzp]. W 2020 r. Ministerstwo Rozwoju słusznie zwróciło uwage na zbyt małe pokrycie kraju planami miejscowymi - niewiele pond 30\% [Założenia reformy systemu planowania i zagospodarowania przestrzennego 2020]. Brak chęci ze strony władz gmin do tworzenia tych planów wynika z różnych powodów:

- $\quad$ z braku pieniędzy na ich wykonanie, a zwłaszcza na ich realizację, np. wykup gruntów pod inwestycje celu publicznego,

- ze zbyt skomplikowanej procedury sporządzania, której naruszenie prowadzi do stwierdzenia nieważności uchwalonego planu przez organ nadzoru (wojewodę),

- $\quad$ z mało precyzyjnego zakresu stanowienia, co również może skutkować stwierdzeniem nieważności.

Niniejszy artykuł poświęcono tej ostatniej z wymienionych przyczyn.

Artykuł oparto na:

- przepisach ustawy o planowaniu i zagospodarowaniu przestrzennym, w szczególności na art. 15 ust. 2 i ust. 3 (odnosząc się do wszystkich punktów tych ustępów) oraz rozporządzeniu w sprawie wymaganego zakresu projektu miejscowego planu zagospodarowania przestrzennego (rozp. mpzp),

- $\quad$ wybranych przepisach odrębnych, ponieważ projekt planu miejscowego sporządza się zgodnie z tymi przepisami [art. 15 ust. 1 upzp],

- własnych doświadczeniach wynikających z pracy nad ponad trzydziestoma projektami planów miejscowych, które zostały uchwalone i stały się aktami prawa miejscowego.

W pełni świadomie, dla zachowania precyzji wypowiedzi posłużono się szeregiem cytatów z obowiązujących aktów prawa. Tylko na podstawie cytatów można wykazać brak precyzji polskiego systemu prawnego.

Nie jest przedmiotem artykułu analizowanie, jak rozumiany jest zakresu planu miejscowego:

- w dokumentach (np. rządowych i sejmowych),

- w orzecznictwie i rozstrzygnięciach nadzorczych wojewodów,

- w obowiązujacych planach miejscowych,

- w literaturze, np. publikacjach prof. Zygmunta Niewiadomskiego i dra hab. Macieja J. Nowaka. Nie jest również przedmiotem artykułu napisanie nowej wersji ustawy o planowaniu i zagospodarowaniu przestrzennym. 


\section{SYSTEM KSZTALTOWANIA PRZESTRZENI}

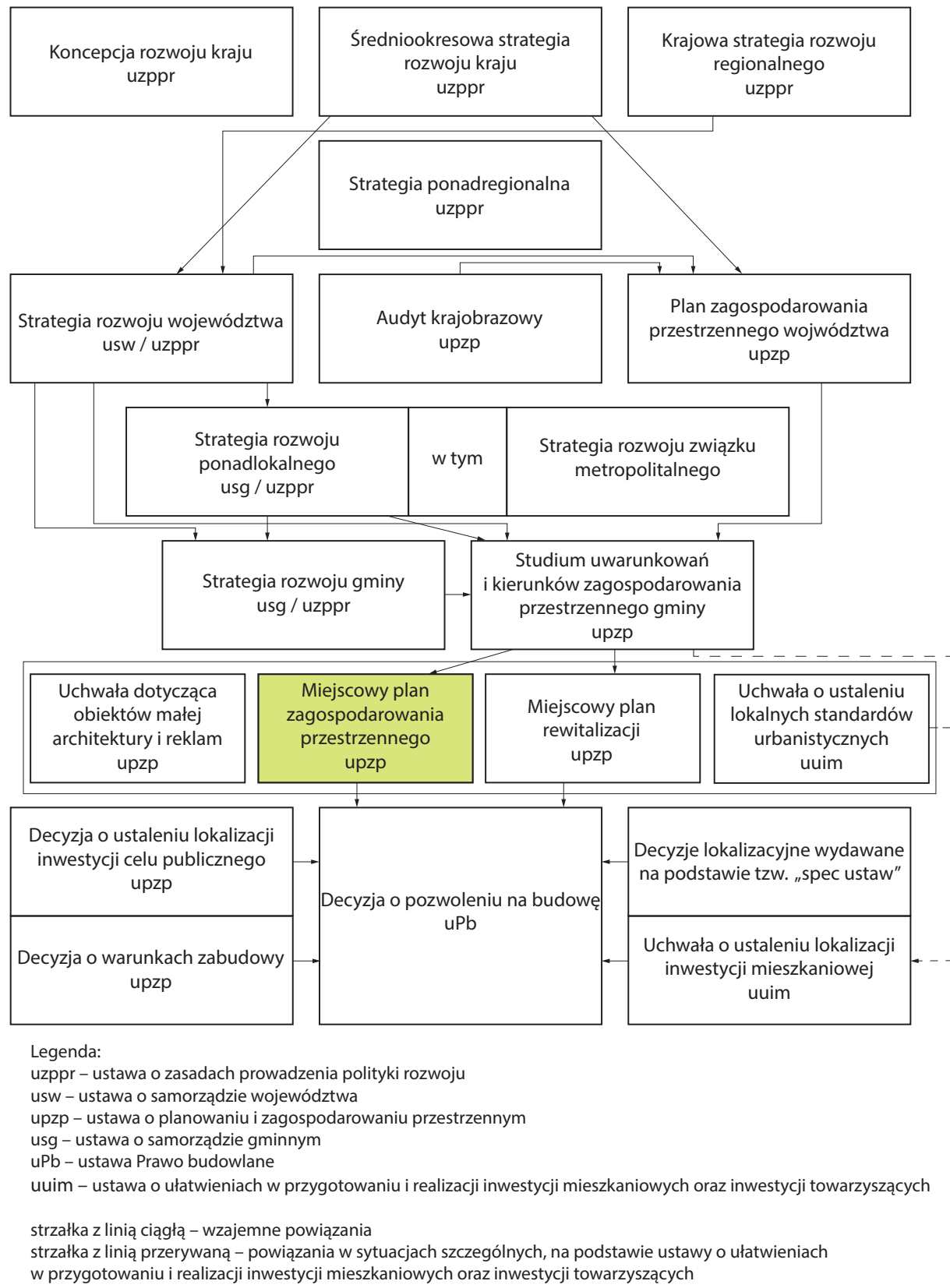

\section{Ryc. 1. System kształtowania przestrzeni}

Źródło: opracowanie własne 


\section{Zakres stanowienia miejscowego planu zagospodarowania przestrzennego}

\section{Przeznaczenie terenów oraz linie rozgraniczające tereny o różnym przeznaczeniu lub różnych zasadach zagospodarowania - zakres obowiązkowy [art. 15 ust. 2 pkt 1 upzp]}

Pojęcia:

- przeznaczenie terenu/ów,

- zagospodarowanie terenu/ów,

- linie rozgraniczające tereny,

nie zostały zdefiniowane $\mathrm{w}$ ustawie o planowaniu i zagospodarowaniu przestrzennym. W rozporządzeniu w sprawie wymaganego zakresu projektu miejscowego planu zagospodarowania przestrzennego napisano jedynie, że „ustalenia dotyczące przeznaczenia terenów powinny zawierać określenie przeznaczenia poszczególnych terenów lub zasad ich zagospodarowania, a także symbol literowy i numer wyróżniający go spośród innych terenów" [§ 4 pkt 1 rozp. mpzp].

Z powyższego wynika, że przeznaczenie i zagospodarowanie to nie to samo, co oznacza, iż:

- tereny o tym samym przeznaczeniu mogą mieć różne zagospodarowanie,

- tereny o tym samym zagospodarowaniu mogą mieć różne przeznaczenie.

Oddzielaja je od siebie linie rozgraniczające, będące jak należy domniemywać i jak jest stosowane w praktyce, oznaczeniem granic tych terenów.

Rozporządzenie w sprawie wymaganego zakresu projektu miejscowego planu zagospodarowania przestrzennego zawiera szereg załączników. Załącznik nr 1 pt. „Podstawowe barwne oznaczenia graficzne i literowe dotyczące przeznaczenia terenów, które należy stosować na projekcie rysunku planu miejscowego (wzór)", dalej Załącznik nr 1, zawiera listę siedmiu podstawowych grup terenów i szereg podgrup (nazwy przytoczono w formie cytatów). Podstawowe grupy, to:

- _Tereny zabudowy mieszkaniowej”

- „Tereny zabudowy usługowej”

- „Tereny użytkowane rolniczo”

- _Tereny zabudowy techniczno-produkcyjnej"

- "Tereny zieleni i wód"

- „Tereny komunikacji”

- " „Tereny infrastruktury technicznej".

Załącznik nr 1 przesądza o sposobie określania przeznaczenia poszczególnych terenów, ale nie przyczynia się do jednoznaczności ustaleń planów miejscowych. Użyte w nim pojęcia są wieloznaczne. Żeby się o tym przekonać, wystarczy porównać kilka tekstów tych planów. Powyższe nazwy wskazują, że przeznaczenie oznacza zbiór elementów, które moga istnieć i powstać na danym terenie, takich jak: zabudowa, infrastruktura techniczna, zieleń czy wody. 
Żadnego z określeń z Załącznika nr 1 nie zdefiniowano w ustawie o planowaniu i zagospodarowaniu przestrzennym oraz $\mathrm{w}$ wydanych na jej podstawie przepisach wykonawczych. Przepisy odrębne zawierają definicje niektórych pojęć oraz określenia bliskoznaczne. Przykładowo - zabudowa, pojęcie powtarzane w nazwach terenów oraz użyte w kilku innych punktach zakresu stanowienia planu miejscowego, nie ma definicji w polskim systemie prawnym.

Rozporządzenie w sprawie warunków technicznych, jakim powinny odpowiadać budynki i ich usytuowanie, (rozp.w.t.) - przepis wykonawczy do ustawy Prawo budowlane $(\mathrm{uPb})$, określa czym jest zabudowa śródmiejska, zabudowa jednorodzinna i zabudowa zagrodowa [§ 3 pkt 1, 2 i 3 rozp.w.t.]. $Z$ analizy tych pojęć można wnioskować, że zabudowa oznacza zespoły budynków lub zespoły obiektów budowlanych. Obiekt budowlany, to budynki, budowle i obiekty małej architektury [art. 3 pkt $1 \mathrm{uPb}$ ].

Przeznaczenie terenów jest kluczowym ustaleniem planów miejscowych. Dlatego temu zagadnieniu poświecono odrębny artykuł pt. Kształtowanie przestrzeni - sprawny system czy chaos? Miejscowy plan zagospodarowania przestrzennego - przeznaczenie terenów, będący uzupełnieniem i rozszerzeniem informacji zawartych w niniejszym artykule.

Brak definicji pojęć: przeznaczenie terenu/ów i zabudowa rzutuje na całość zakresu stanowienia planu miejscowego. Jest podstawowa przyczyną wieloznaczności i braku precyzji.

\section{Zasady ochrony i kształtowania ładu przestrzennego - zakres obowiązkowy}

[art. 15 ust. 2 pkt 2 upzp]

Ład przestrzenny, to „takie ukształtowanie przestrzeni, które tworzy harmonijną całość oraz uwzględnia $\mathrm{w}$ uporządkowanych relacjach wszelkie uwarunkowania i wymagania funkcjonalne, społeczno-gospodarcze, środowiskowe, kulturowe oraz kompozycyjno-estetyczne" [art. 2 pkt 1 upzp].

Ustalenia dotyczace ochrony tego ładu powinny zawierać „określenie cech elementów zagospodarowania przestrzennego, które wymagają ochrony, określenie cech elementów zagospodarowania przestrzennego, które wymagają ukształtowania lub rewaloryzacji, oraz określenie nakazów, zakazów, dopuszczeń i ograniczeń w zagospodarowaniu terenów" [§ 4 pkt 2 rozp. mpzp].

Elementy zagospodarowania przestrzennego, to „w szczególności istniejące i projektowane pierzeje ulic, place miejskie, osie i punkty widokowe, dominanty kompozycji przestrzennej, charakterystyczne obiekty, a także tereny zieleni" [§ 2 pkt 7 rozp. mpzp].

Jeśli nakazuje się ochronę i kształtowanie ładu przestrzennego, to trzeba określić, czym jest ten ład. Sądząc po wyjątkowo nieprecyzyjnej definicji oraz rozbieżności w rozumieniu tego pojęcia pomiędzy ustawą a przepisem wykonawczym zrobić się tego nie da. 


\section{Zasady ochrony środowiska, przyrody i krajobrazu - zakres obowiązkowy} [art. 15 ust. 2 pkt 3 upzp]

Ustalenia dotyczące „zasad ochrony środowiska, przyrody i krajobrazu kulturowego powinny zawierać nakazy, zakazy, dopuszczenia i ograniczenia w zagospodarowaniu terenów wynikające z:

a) potrzeb ochrony środowiska, o których mowa w szczególności w art. 72 i 73 ustawy (...) Prawo ochrony środowiska (...),

b) obowiązujących ustaleń planów ochrony ustanowionych dla parków narodowych, rezerwatów przyrody i parków krajobrazowych, a także dla innych form ochrony przyrody występujacych na terenach objętych projektem planu miejscowego" [§ 4 pkt 3 rozp. mpzp].

Ustawa o planowaniu i zagospodarowaniu przestrzennym odróżnia środowisko od przyrody i krajobrazu. Jednocześnie w sposób niekonsekwentny:

- odsyła do definicji pojęcia środowisko zawartej w ustawie Prawo ochrony środowiska (Poś), w której przyroda i krajobraz są składowymi środowiska,

- definiuje pojęcie krajobraz, a w przepisie wykonawczym odnosi się do krajobrazu kulturowego.

Środowisko oznacza „ogół elementów przyrodniczych, w tym także przekształconych w wyniku działalności człowieka, a w szczególności powierzchnię ziemi, kopaliny, wody, powietrze, krajobraz, klimat oraz pozostałe elementy różnorodności biologicznej, a także wzajemne oddziaływania pomiędzy tymi elementami" [art. 2 pkt 3 upzp w związku z art. 3 pkt 39 Poś].

Pod pojęciem krajobraz należy rozumieć „postrzeganą przez ludzi przestrzeń, zawierającą elementy przyrodnicze lub wytwory cywilizacji, ukształtowaną w wyniku działania czynników naturalnych lub działalności człowieka" [art. 2 pkt 16e upzp].

Ustawa Prawo ochrony środowiska w większym lub mniejszym stopniu odnosi się do wszystkich terenów wyznaczonych w planach miejscowych. Nakazuje, aby przy przeznaczaniu terenów ustalić „proporcje pozwalające na zachowanie lub przywrócenie na nich równowagi przyrodniczej i prawidłowych warunków życia” [art. 72 ust. 2 Poś].

Utrzymanie równowagi przyrodniczej należy zapewnić poprzez:

- racjonalne wykorzystanie powierzchni ziemi, w tym zapobieganie jej masowym ruchom oraz uwzględnienie eksploatacji złóż kopalin [art. 72 ust. 1 pkt 1, 2 i 5a Poś],

- zapewnianie kompleksowych rozwiązań dotyczących gospodarki wodnej, odprowadzania ścieków, gospodarki odpadami, systemów transportowych oraz terenów zieleni [art. 72 ust. 1 pkt 3 Poś],

- $\quad$ ochronę walorów krajobrazowych i warunków klimatycznych środowiska [art. 72 ust. 1 pkt 5 Poś],

- ochronę przed zanieczyszczeniami wód, gleby i ziemi oraz ochronę przed hałasem, wibracjami i polami elektromagnetycznymi [art. 72 ust. 1 pkt 4 i 6 Poś], 
- określenie „zagospodarowania obszarów zdegradowanych w wyniku działalności człowieka, klęsk żywiołowych oraz ruchów masowych ziemi" [art. 72 ust. 3 Poś].

Ponadto w planie miejscowym należy uwzględnić ograniczenia wynikające z:

- form ochrony przyrody,

- obszarów ograniczonego użytkowania i stref przemysłowych,

- obszarów cichych w aglomeracji i poza aglomeracją oraz strategicznych map hałasu,

- stref ochronnych ujęć wód oraz obszarów ochronnych zbiorników wód śródlądowych [art. 73 ust. 1 pkt 1 do 3 Poś],

- stwarzających zagrożenie dla życia lub zdrowia ludzi zakładów, które należy lokalizować w bezpiecznej odległości od siebie i od innych obiektów budowlanych [art. 73 ust. 3 i ust. 4 Poś].

Przepis art. 15 ust. 2 pkt 3 ustawy o planowaniu i zagospodarowaniu przestrzennym jest tak sformułowany, że nie wiadomo, czy zasady ochrony środowiska, przyrody i krajobrazu są podstawą ustaleń planu miejscowego, w szczególności przeznaczenia terenów, czy należy je określić niezależnie od innych ustaleń takiego planu.

Ustawa Prawo ochrony środowiska wprowadza szereg wymagań, które nie tyle zależą od ustaleń planu, a od rozwiązań technicznych i innych przepisów. Czystość powietrza, wody i gleby oraz ochrona przed hałasem, wibracjami i polami elektromagnetycznymi, zależą od zastosowania odpowiednich urządzeń i metod postępowania. W planie miejscowym można nakazać taką ochronę, ale sporządzający plan nie ma wpływu na jej skuteczność.

Złożami kopalin oraz zapobieganiem ruchom ziemi spowodowanym ich eksploatacja zajmuje się ustawa Prawo geologiczne i górnicze (uPg). Definiuje, czym jest obszar górniczy [art. 6 ust. 1 pkt 5 uPg] i teren górniczy [art. 6 ust. 1 pkt 15 uPg].

Do form ochrony przyrody odnosi się ustawa o ochronie przyrody (uop). Formami ochrony przyrody sa: parki narodowe, rezerwaty przyrody, parki krajobrazowe, obszary chronionego krajobrazu, obszary Natura 2000, pomniki przyrody, stanowiska dokumentacyjne, użytki ekologiczne, zespoły przyrodniczo-krajobrazowe oraz ochrona gatunkowa roślin, zwierząt i grzybów" [art. 6 ust. 1 uop].

Powyższe dwie ustawy, to przepisy odrębne zarówno do ustawy o planowaniu i zagospodarowaniu przestrzennym, jak i ustawy Prawo ochrony środowiska. Sporządzający plan miejscowy nie ma wpływu na wyznaczanie obszarów, których dotyczą.

Powyższe przykłady wskazują na konieczność uporządkowania relacji pomiędzy ustawą o planowaniu i zagospodarowaniu przestrzennym a przepisami odrębnymi dotyczącymi szeroko rozumianego środowiska.

Zasady kształtowania krajobrazu - zakres obowiązkowy [art. 15 ust. 2 pkt 3a upzp]

Ustawodawca nie wyjaśnia, czym się różni ochrona krajobrazu od kształtowania krajobrazu. To powtórzenie wymienionych powyżej wymagań stawianych planom miejscowym. 


\section{Zasady ochrony dziedzictwa kulturowego i zabytków, w tym krajobrazów kulturowych, oraz dóbr kultury współczesnej - zakres obowiązkowy [art. 15 ust. 2 pkt 4 upzp]}

Ustalenia dotyczace „zasad ochrony dziedzictwa kulturowego i zabytków oraz dóbr kultury współczesnej powinny zawierać określenie obiektów i terenów chronionych ustaleniami miejscowego planu zagospodarowania przestrzennego, w tym określenie nakazów, zakazów, dopuszczeń i ograniczeń w zagospodarowaniu terenów" [§ 4 pkt 4 rozp. mpzp].

Z powyższego wynika, że ustalenia planów miejscowych dotyczą wyłącznie obiektów i terenów chronionych tymi planami. Tymczasem, ustawa o ochronie zabytków i opiece nad zabytkami (uoz) stanowi, że ochronę zabytków - wszystkich zabytków - uwzględnia się przy sporządzaniu planów miejscowych [art. 18 ust. 1 uoz], w których:

- „określa się rozwiązania niezbędne do zapobiegania zagrożeniom dla zabytków, zapewnienia im ochrony przy realizacji inwestycji oraz przywracania zabytków do jak najlepszego stanu" [art. 18 ust. 2 pkt 2 uoz],

- _ustala się przeznaczenie i zasady zagospodarowania terenu uwzględniające opiekę nad zabytkami" [art. 18 ust. 2 pkt 2 uoz].

Ustanawia się pięć form ochrony zabytków, z których tylko jedna polega na ustaleniu ochrony w planie miejscowym [art. 7 pkt 4 uoz]. Pozostałe formy, to „wpis do rejestru zabytków”, , wwis na Listę Skarbów Dziedzictwa”, ,uznanie za pomnik historii” oraz „utworzenie parku kulturowego" [art. 7 pkt 1, pkt 1a, pkt 2 i pkt 3 uoz].

Park kulturowy tworzy się w celu ochrony krajobrazu kulturowego, na podstawie uchwały rada gminy [art. 16 ust. 1 uoz]. Krajobraz kulturowy, to „postrzegana przez ludzi przestrzeń, zawierająca elementy przyrodnicze i wytwory cywilizacji, historycznie ukształtowana w wyniku działania czynników naturalnych i działalności człowieka” [art. 3 pkt 14 uoz].

Zabytek, to „nieruchomość lub rzecz ruchoma, ich części lub zespoły, będące dziełem człowieka lub związane z jego działalnością i stanowiące świadectwo minionej epoki bądź zdarzenia, których zachowanie leży w interesie społecznym ze względu na posiadaną wartość historyczną, artystyczną lub naukowa" [art. 3 pkt 1 uoz].

Jednym z rodzajów zabytków jest krajobraz kulturowy [art. 6 ust. 1 pkt 1 ppkt a uoz].

Dobra kultury współczesnej, to „niebędące zabytkami dobra kultury, takie jak pomniki, miejsca pamięci, budynki, ich wnętrza i detale, zespoły budynków, założenia urbanistyczne i krajobrazowe, będące uznanym dorobkiem współcześnie żyjących pokoleń, jeżeli cechuje je wysoka wartość artystyczna lub historyczna" [art. 2 pkt 10 upzp].

Nie znaleziono definicji pojęcia dziedzictwo kulturowe.

Prócz form ochrony zabytków istnieje ewidencja zabytków - zbiór danych, które służą np. do sporządzania programów opieki nad zabytkami [art. 21 uoz]. Nie wszystkie obiekty wymienione w ewidencji zabytków są objęte formami ochrony zabytków.

Podobnie jak w przypadku środowiska, przepis art. 15 ust. 2 pkt 4 ustawy o planowaniu i zagospodarowaniu przestrzennym jest tak sformułowany, że nie wiadomo, czy zasady ochrony zabytków należy określić niezależnie od innych ustaleń planu miejscowego, czy kierować się nimi formułując ustalenia takiego planu. 
Krajobraz i krajobraz kulturowy są definiowane niemalże identyczne. Nie wiadomo dlaczego odróżnia się od siebie te dwa pojęcia. Ochrona krajobrazu dwoma uchwałami tej samej rady gminy, podejmowanymi na podstawie dwóch różnych ustaw, to zbędne powtórzenie. Ponadto o krajobrazie kulturowym była już mowa w punkcie dotyczącym środowiska.

Skoro nie wszystkie zabytki są objęte formami ochrony, to trudno ustalić czym się różni zabytek od dobra kultury współczesnej. Przywracanie zabytków do jak najlepszego stanu, jak należy domniemywać - stanu technicznego, nie zależy od ustaleń planu.

Powyższe przykłady wskazują na konieczność uporządkowania relacji pomiędzy ustawą o planowaniu i zagospodarowaniu przestrzennym, ustawą o ochronie zabytków i opiece nad zabytkami oraz przepisami dotyczącymi środowiska.

Wymagania wynikające z potrzeb kształtowania przestrzeni publicznych - zakres obowiązkowy [art. 15 ust. 2 pkt 5 upzp]

Ustalenia dotyczące „wymagań wynikających z potrzeb kształtowania przestrzeni publicznych powinny zawierać w szczególności określenie zasad umieszczania w przestrzeni publicznej obiektów małej architektury, nośników reklamowych, tymczasowych obiektów usługowo-handlowych, urządzeń technicznych i zieleni, w tym określenie nakazów, zakazów, dopuszczeń i ograniczeń w zagospodarowaniu terenów" [§ 4 pkt 5 rozp. mpzp].

Ustawa o planowaniu i zagospodarowaniu przestrzennym nie definiuje pojęcia przestrzenie publiczne i jednocześnie posługuje się określeniami bliskoznacznymi:

- obszar przestrzeni publicznej, to „obszar o szczególnym znaczeniu dla zaspokojenia potrzeb mieszkańców, poprawy jakości ich życia i sprzyjający nawiązywaniu kontaktów społecznych ze względu na jego położenie oraz cechy funkcjonalno-przestrzenne, określony w studium uwarunkowań i kierunków zagospodarowania przestrzennego gminy" [art. 2 pkt 6 upzp],

- $\quad$ tereny publicznie dostępne [ art. 15 ust. 3 pkt 8 upzp], bez definicji.

Wejście w życie w 2015 r. ustawy o zmianie niektórych ustaw w związku ze wzmocnieniem narzędzi ochrony krajobrazu spowodowało, że zasady umieszczania obiektów małej architektury i nośników reklamowych rada gminy ustala w odrębnej uchwale [art. 37a ust. 1-4 upzp]. Wniosek - sporządzający plan miejscowy utracił delegację ustawową do określania zasad lokalizowania tych obiektów.

Przeczy temu zakres fakultatywny planu miejscowego, w świetle którego można ustalać „sposób usytuowania obiektów budowlanych w stosunku do dróg i innych terenów publicznie dostępnych" [art. 15 ust. 3 pkt 8 upzp]. W rozumieniu ustawy Prawo budowlane obiektami budowlanymi są obiekty małej architektury oraz urządzenia reklamowe [art. 3 pkt 1 , pkt 3 i pkt $4 \mathrm{uPb}$.

Relacje między planem miejscowym a uchwałą dotyczącą obiektów małej architektury i reklam wymagają uporządkowania. Pomogłoby w tym zdefiniowanie pojęcia przestrzeń publiczna i eliminacja określeń bliskoznacznych. 


\begin{abstract}
Zasady kształtowania zabudowy oraz wskaźniki zagospodarowania terenu, maksymalna i minimalna intensywność zabudowy jako wskaźnik powierzchni całkowitej zabudowy w odniesieniu do powierzchni działki budowlanej, minimalny udział procentowy powierzchni biologicznie czynnej w odniesieniu do powierzchni działki budowlanej, maksymalna wysokość zabudowy, minimalna liczba miejsc do parkowania w tym miejsc przeznaczonych na parkowanie pojazdów zaopatrzonych w kartę parkingową i sposób ich realizacji oraz linie zabudowy i gabaryty obiektów - zakres obowiązkowy [art. 15 ust. 2 pkt 6 upzp].
\end{abstract}

Ustalenia dotyczące „parametrów i wskaźników kształtowania zabudowy oraz zagospodarowania terenu powinny zawierać w szczególności określenie linii zabudowy, wielkości powierzchni zabudowy w stosunku do powierzchni działki lub terenu, w tym udziału powierzchni biologicznie czynnej, a także gabarytów i wysokości projektowanej zabudowy oraz geometrii dachu" [§ 4 pkt 6 rozp. mpzp].

Nie wiadomo czym się różnią od siebie określenia bliskoznaczne, takie jak:

- zasady zagospodarowania terenów [art. 15 ust. 2 pkt 1 upzp],

- zasady kształtowania zabudowy oraz wskaźniki zagospodarowania terenu

[art. 15 ust. 2 pkt 6 upzp],

- parametry i wskaźniki kształtowania zabudowy oraz zagospodarowania terenu

[§ 4 pkt 6 rozp. mpzp],

- parametry dotyczace zagospodarowania przestrzennego [art. 2 pkt 15 upzp],

- parametry i wskaźniki urbanistyczne [art. 2 pkt 16 upzp].

To ostatnie określenie zdefiniowano jako „parametry i wskaźniki ustanawiane w dokumentach planistycznych, zgodnie z przepisami wydanymi na podstawie (...) art. 16 ust. 2" [art. 2 pkt 16 upzp]. Na podstawie powyższego artykułu wydano rozporządzenie w sprawie wymaganego zakresu projektu miejscowego planu zagospodarowania, które niczego nie wyjaśnia.

Ustawa o planowaniu i zagospodarowaniu przestrzennym i powyższe rozporządzenie nie definiuja pojęć:

- powierzchnia biologicznie czynna,

- wysokość zabudowy,

- linie zabudowy,

- gabaryty obiektów i gabaryty zabudowy,

- geometria dachu.

Wyjatkowo wieloznaczna jest definicja intensywności zabudowy, w szczególności jej część - powierzchnia całkowitej zabudowy - utożsamiana np. z suma powierzchni zabudowy albo z powierzchnia całkowitą budynku. Brak jednoznaczności pogłębia fakt, że pojęcie powierzchnia zabudowy różnie definiuja przepisy odrębne.

Podobnie jak w nazwach terenów wymienionych w Załączniku nr 1 - słowo, które się powtarza to zabudowa, i podobnie jak przy określaniu przeznaczenia terenów, nie wiadomo co oznacza. 
Odniesienie do powyższych zagadnień można znaleźć w literaturze [Nowak 2019; Stelmach-Fita, Wieczorek 2019], rozstrzygnięciach nadzorczych wojewodów i wyrokach sadów administracyjnych.

Ze względu na wyjątkowo dużo kontrowersji, które budzi przepis art. 15 ust. 2 pkt 6 ustawy o planowaniu i zagospodarowaniu przestrzennym, poświęcono mu artykuł pt. Kształtowanie przestrzeni - sprawny system czy chaos? Miejscowy plan zagospodarowania przestrzennego parametry zabudowy, który jest uzupełnieniem niniejszego artykułu i trzecim z serii dotyczącej zakresu stanowienia planów miejscowych.

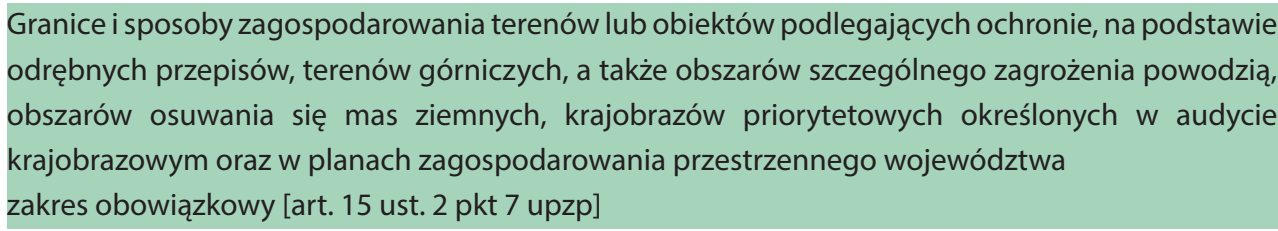

Ustalenia dotyczące "granic i sposobów zagospodarowania terenów lub obiektów podlegających ochronie, ustalonych na podstawie odrębnych przepisów, w tym terenów górniczych, a także narażonych na niebezpieczeństwo powodzi oraz zagrożonych osuwaniem się mas ziemnych, powinny zawierać nakazy, zakazy, dopuszczenia i ograniczenia w zagospodarowaniu terenów" [§ 4 pkt 7 rozp. mpzp].

Przepisami odrębnymi są przepisy dotyczące środowiska i zabytków [art. 15 ust. 2 pkt 3 i pkt 4 upzp]. Przykładowo, wymagania dotyczące złóż kopalin i zapobiegania ruchom ziemi postawiono już w punkcie dotyczącym środowiska. Co więcej, w Załączniku nr 1, jedna z podgrup terenów o nazwie „Tereny zabudowy techniczno-produkcyjnej” sa „Obszary i tereny górnicze”. Podobnie można domniemywać, że tereny narażone na niebezpieczeństwo powodzi, to według Załącznika nr 1 „Tereny zieleni i wód”, podgrupa o nazwie „Obszary zagrożone powodzią".

O ochronie krajobrazu jest mowa po raz czwarty, tym razem o krajobrazie priorytetowym, którego definicja niewiele się różni od definicji krajobrazu i krajobrazu kulturowego [art. 2 pkt $16 \mathrm{f}$ upzp].

Szczegółowe zasady i warunki scalania i podziału nieruchomości objętych planem miejscowym zakres obowiązkowy [ art. 15 ust. 2 pkt 8 upzp]

Ustalenia dotyczące „szczegółowych zasad i warunków scalania i podziału nieruchomości powinny zawierać określenie parametrów działek uzyskiwanych w wyniku scalania i podziału nieruchomości, w szczególności minimalnych lub maksymalnych szerokości frontów działek, ich powierzchni oraz określenie kąta położenia granic działek w stosunku do pasa drogowego" [§ 4 pkt 8 rozp. mpzp]. 
Ustawa o gospodarce nieruchomościami (ugn) ustala zasady wydzielania działek gruntu w ramach:

- $\quad$ procedury podziału nieruchomości [Dział III, Rozdział 1 ugn], której „nie stosuje się do nieruchomości położonych na obszarach przeznaczonych w planach miejscowych na cele rolne i leśne" [art. 92 ust. 1 ugn],

- $\quad$ procedury scalania i podział nieruchomości [Dział III, Rozdział 2 ugn], która dotyczy „nieruchomości położonych na obszarach przeznaczonych w planach miejscowych na cele inne niż rolne i leśne" [art. 101 ust. 2 ugn].

Ponadto procedury podziału gospodarstw rolnych i lasów ustala ustawa o scalaniu i wymianie gruntów. Ustawa o planowaniu i zagospodarowaniu przestrzennym i cytowane powyżej rozporządzenie nie precyzuja, o którą z procedur oraz o parametry jakich działek chodzi.

W polskim systemie prawnym występuja pojęcia:

- działka budowlana, która doczekała się aż trzech definicji,

- działka gruntu, w rozumieniu ustawy o gospodarce nieruchomościami,

- działka ewidencyjna, w rozumieniu rozporządzenia w sprawie ewidencji gruntów i budynków (rozp. eg).

Działka budowlana, to:

- nieruchomość gruntowa lub działka gruntu, „której wielkość, cechy geometryczne, dostęp do drogi publicznej oraz wyposażenie w urządzenia infrastruktury technicznej spełniają wymogi realizacji obiektów budowlanych wynikające z odrębnych przepisów i aktów prawa miejscowego" [art. 2 pkt 12 upzp],

albo

- zabudowana działka gruntu, „której wielkość, cechy geometryczne, dostęp do drogi publicznej oraz wyposażenie w urządzenia infrastruktury technicznej umożliwiaja prawidłowe i racjonalne korzystanie z budynków i urządzeń położonych na tej działce" [art. 4 pkt 3a ugn],

albo

- nieruchomość gruntowa lub działka gruntu, „której wielkość, cechy geometryczne, dostęp do drogi publicznej oraz wyposażenie w urządzenia infrastruktury technicznej spełniają wymogi realizacji obiektów budowlanych wynikające z rozporządzenia, odrębnych przepisów i aktów prawa miejscowego" [§ 3 pkt 1a rozp.w.t.].

Pod pojęciem działka gruntu, należy rozumieć „niepodzielona, ciagłą część powierzchni ziemskiej stanowiąca część lub całość nieruchomości gruntowej” [art. 4 pkt 3 ugn].

„Działkę ewidencyjną stanowi ciagły obszar gruntu, położony w granicach jednego obrębu ewidencyjnego, jednorodny pod względem prawnym, wydzielony z otoczenia za pomoca granic działek ewidencyjnych." [§ 7 ust. 1 rozp. eg]

Przyjmując, że plan miejscowy określa warunki scalenia i podziału nieruchomości [art. 102 ust. 1 ugn], to:

- rada gminy, w drodze uchwały, decyduje o rozpoczęciu tej procedury i określa granice zewnętrzne gruntów objętych scalaniem [art. 102 ust. 3 ugn], 
- procedura ma na celu doprowadzenie do "ponownego podziału na działki gruntu” [art. 101 ust. 1 ugn], co oznaczałoby, że w planie miejscowym należy określić parametry działek gruntu.

Wymaga zastanowienia, czy zagadnienia scalania i podziału nieruchomości powinny być powiązane z ustaleniami planów miejscowych. Jeśli tak, to należy:

- sprecyzować, o którą z powyżej wymienionych procedur chodzi,

- $\quad$ ustalić, których działek parametry należy określić.

\section{Szczególne warunki zagospodarowania terenów oraz ograniczenia w ich użytkowaniu,} w tym zakaz zabudowy - zakres obowiązkowy [ art. 15 ust. 2 pkt 9 upzp]

Powraca problem braku definicji pojęć zagospodarowanie terenów oraz zabudowa. Przykładowo - czy zakaz zabudowy rozumieć jako zakaz wznoszenia budynków, czy jako zakaz wznoszenia wszystkich obiektów budowlanych i urządzeń budowlanych, o których mowa w ustawie Prawo budowlane?

Nie wiadomo, czym różni się zagospodarowanie terenów od użytkowania terenów. W powszechnym odczuciu te bliskoznaczne pojęcia oznaczają to samo.

\section{Zasady modernizacji, rozbudowy i budowy systemów komunikacji i infrastruktury technicznej zakres obowiązkowy [art. 15 ust. 2 pkt 10 upzp]}

Ustalenia dotyczące „zasad modernizacji, rozbudowy i budowy systemów komunikacji i infrastruktury technicznej powinny zawierać:

a) określenie układu komunikacyjnego i sieci infrastruktury technicznej wraz z ich parametrami oraz klasyfikacją ulic i innych szlaków komunikacyjnych,

b) określenie warunków powiązań układu komunikacyjnego i sieci infrastruktury technicznej z układem zewnętrznym,

c) wskaźniki w zakresie komunikacji i sieci infrastruktury technicznej, w szczególności ilość miejsc parkingowych w stosunku do ilości mieszkań lub ilości zatrudnionych albo powierzchni obiektów usługowych i produkcyjnych" [§ 4 pkt 9 rozp. mpzp].

Ustawa o planowaniu i zagospodarowaniu przestrzennym oraz powyższe rozporządzenie nie definiują pojęć:

- $\quad$ system komunikacji i infrastruktury technicznej,

- układ komunikacyjny i sieci infrastruktury technicznej,

- parametry oraz klasyfikacja ulic i innych szlaków komunikacyjnych,

- $\quad$ wskaźniki w zakresie komunikacji i sieci infrastruktury technicznej.

Zamiast tego, powyższa ustawa określa czym jest uzbrojenie terenu. To „drogi, obiekty budowlane, urządzenia i przewody, o których mowa w art. 143 ust. 2 ustawy (...) o gospodarce nieruchomościami" [art.2 pkt 13 upzp]. Ustawa o gospodarce nieruchomościami stanowi: 
„Przez budowę urządzeń infrastruktury technicznej rozumie się budowę drogi oraz wybudowanie pod ziemia, na ziemi albo nad ziemia przewodów lub urządzeń wodociagowych, kanalizacyjnych, ciepłowniczych, elektrycznych, gazowych i telekomunikacyjnych" [art. 143 ust. 2 ugn].

Z powyższego wynika, że drogi to urządzenia infrastruktury technicznej. Tymczasem według Załącznika nr 1 „Tereny komunikacji” to nie to samo, co „Tereny infrastruktury technicznej”. To „Tereny komunikacji” zawieraja podgrupy „Tereny dróg publicznych” i „Tereny dróg wewnętrznych".

Plan miejscowy uchwala rada gminy rozstrzygając m.in. o sposobie realizacji, „inwestycji z zakresu infrastruktury technicznej, które należą do zadań własnych gminy" [art. 20 ust. 1 upzp]. Powyższe rozstrzygnięcie stanowi załącznik do uchwały. Nie wiadomo, czy w tym załączniku umieszczać drogi publiczne. Nie znaleziono przepisu, który stanowi, że infrastruktura techniczna znaczy to samo, co uzbrojenie terenu.

Podobnie jak w przypadku środowiska i zabytków, przepisy dotyczące komunikacji i infrastruktury technicznej są tak sformułowane, jakby należało się do nich odnosić niezależnie od innych ustaleń planu miejscowego, a de facto sprowadzają się do określenia przeznaczenia terenu/ów.

Zdefiniowanie pojęć wieloznacznych i usunięcie określeń bliskoznacznych wyeliminowałoby niepotrzebne watpliwości i powtórzenia.

Sposób i termin tymczasowego zagospodarowania, urządzania i użytkowania terenów zakres obowiązkowy [art. 15 ust. 2 pkt 11 upzp]

Ustalenia dotyczące „sposobów i terminów tymczasowego zagospodarowania, urządzenia i użytkowania terenów powinny zawierać nakazy, zakazy, dopuszczenia i ograniczenia w zagospodarowaniu terenów, w tym określenie terminu, do którego tymczasowe zagospodarowanie, urządzenie i użytkowanie terenu może być wykonywane" [§ 4 pkt 10 rozp. mpzp]. Jak już napisano, brakuje definicji pojęć zagospodarowanie terenów i użytkowanie terenów. Bardzo trudno określić, kiedy ustalenia planów miejscowych zostaną zrealizowane. Dlatego funkcjonuje formuła „do czasu realizacji ustaleń planu” - martwy przepis.

Stawki procentowe, na podstawie których ustala się opłatę, o której mowa w art. 36 ust. 4 zakres obowiązkowy [art. 15 ust. 2 pkt 12 upzp]

Ustalenia dotyczące „stawek procentowych stanowiących podstawę do określania opłaty, o której mowa w art. 36 ust. 4 ustawy, powinny zawierać stawki procentowe w przedziale od $0 \%$ do 30\% i dotyczyć wszystkich terenów, określonych w projekcie planu miejscowego zgodnie z art. 15 ust. 2 pkt 1 ustawy, przy czym ich wielkość może być różna dla poszczególnych terenów lub grup terenów" [§ 4 pkt 13 rozp. mpzp]. 
Przepis art. 36 ust. 4 ustawy o planowaniu i zagospodarowaniu przestrzennym dotyczy terenów, których wartość wzrasta na skutek uchwalenia planu miejscowego. Powyższe tereny wyznacza się na podstawie prognozy skutków finansowych uchwalenia planu miejscowego, a prognozy nie zawsze się spełniają.

Nie wiadomo, kto może takie prognozy wykonywać - czy tylko rzeczoznawcy majątkowi, czy wszyscy, którzy spełniają warunki wymienione w art. 5 ustawy o planowaniu i zagospodarowaniu przestrzennym, np. architekci.

Granice obszarów wymagających przeprowadzenia scaleń i podziałów nieruchomości zakres fakultatywny [art. 15 ust. 3 pkt 1 upzp]

Jak już napisano, można domniemywać, że ustawa o planowaniu i zagospodarowaniu przestrzennym odnosi się do procedury scalania i podziału nieruchomości, o której mowa w Rozdziale 2. Działu III ustawy o gospodarce nieruchomościami. Jest niezrozumiałym, dlaczego do granic powyższych obszarów odniesiono się w zakresie fakultatywnym.

Granice obszarów rehabilitacji istniejącej zabudowy i infrastruktury technicznej zakres fakultatywny [art. 15 ust. 3 pkt 2 upzp]

Ustawa o planowaniu i zagospodarowaniu przestrzennym nie definiuje pojęcia rehabilitacja. Ponownie wraca problem braku definicji pojęć zabudowa oraz infrastruktura techniczna.

Granice obszarów wymagających przekształceń lub rekultywacji - zakres fakultatywny [art. 15 ust. 3 pkt 3 upzp]

Ustawa o planowaniu i zagospodarowaniu przestrzennym nie definiuje pojęcia rekultywacja. Nie określa również o jakie przekształcenia chodzi. Każda dokonana w planie miejscowym zmiana dotychczasowego przeznaczenia terenu będzie powodować przekształcenie takiego obszaru.

Granice terenów pod budowę urządzeń, o których mowa w art. 10 ust. 2a, oraz granice ich stref ochronnych związanych z ograniczeniami w zabudowie, zagospodarowaniu i użytkowaniu terenu oraz występowaniem znaczącego oddziaływania tych urządzeń na środowisko zakres fakultatywny [art. 15 ust. 3 pkt 3a upzp] 
Urządzenia, o których mowa powyżej, to „urządzenia wytwarzające energię z odnawialnych źródeł energii o mocy przekraczającej 100 kW” [art. 10 ust. 2a upzp]. Tereny, na których zapewne można je lokalizować, to „Tereny infrastruktury technicznej” w rozumieniu Załącznika nr 1.

\section{Granice terenów pod budowę obiektów handlowych, o których mowa w art. 10 ust. 3a} zakres fakultatywny [art. 15 ust. 3 pkt 4 upzp]

Obiekty, o których mowa w tym przepisie, to obiekty handlowe o powierzchni sprzedaży powyżej $2000 \mathrm{~m}^{2}$ [art. 10 ust. 3a upzp]. Tereny, na których można je lokalizować określa Załącznika nr 1.

Granice terenów rozmieszczenia inwestycji celu publicznego o znaczeniu lokalnym zakres fakultatywny [art. 15 ust. 3 pkt 4a upzp]

Inwestycje celu publicznego, to „działania o znaczeniu lokalnym (gminnym) i ponadlokalnym (powiatowym, wojewódzkim i krajowym), a także krajowym (obejmującym również inwestycje międzynarodowe i ponadregionalne), oraz metropolitalnym (obejmującym obszar metropolitalny) bez względu na status podmiotu podejmującego te działania oraz źródła ich finansowania, stanowiące realizację celów, o których mowa w art. 6 ustawy (...) o gospodarce nieruchomościami" [art. 2 pkt 5 upzp].

Celami publicznymi są np.: drogi publiczne, drogi wodne, linie kolejowe, lotniska, porty, przewody i urządzenia służące do przesyłania lub dystrybucji płynów, pary, gazów i energii elektrycznej, urządzenia służące do zaopatrzenia ludności w wodę, odprowadzania ścieków oraz odzysku i unieszkodliwiania odpadów, urzędy, sądy, poczty, szkoły, obiekty ochrony zdrowia, obiekty obronności państwa, zakłady karne, cmentarze, parki itp. [art. 6 ugn].

Tak zdefiniowane cele publiczne określają przeznaczenie terenów. Granicami inwestycji będą linie rozgraniczające, a tereny, na których mogą być położone określa Załącznik nr 1 .

Niezrozumiałym jest, dlaczego inwestycje celu publicznego znalazły się w zakresie fakultatywnym. Niemalże każdy plan miejscowy określa np. położenie dróg.

Granice terenów inwestycji celu publicznego o znaczeniu ponadlokalnym umieszczonych w planie zagospodarowania przestrzennego województwa lub w ostatecznych decyzjach o lokalizacji drogi krajowej, wojewódzkiej lub powiatowej, linii kolejowej o znaczeniu państwowym, lotniska użytku publicznego, inwestycji w zakresie terminalu, przedsięwzięcia Euro 2012 lub decyzji lokalizacyjnych wydanych przez Komisję Planowania przy Radzie Ministrów w związku z realizacją inwestycji w zakresie obronności i bezpieczeństwa państwa - zakres fakultatywny [art. 15 ust. 3 pkt 4b upzp] 
Inwestycje celu publicznego o znaczeniu ponadlokalnym, to działania wymienione powyżej, czyli określenie przeznaczenia terenów. Komentarz - jak wyżej.

Granice terenów rekreacyjno-wypoczynkowych oraz terenów służących organizacji imprez masowych - zakres fakultatywny [art. 15 ust. 3 pkt 5 upzp]

Ustawa o planowaniu i zagospodarowaniu przestrzennym nie definiuje pojęć tereny rekreacyjno-wypoczynkowe oraz imprezy masowe. Można domniemywać, że chodzi o wymienione w Załączniku nr 1 „Tereny sportu i rekreacji” albo „Tereny zieleni i wód”, czyli o określenie przeznaczenia terenów.

Granice pomników zagłady oraz ich stref ochronnych, a także ograniczenia dotyczące prowadzenia na ich terenie działalności gospodarczej, określone w ustawie z dnia 7 maja 1999 r. o ochronie terenów byłych hitlerowskich obozów zagłady - zakres fakultatywny [art. 15 ust. 3 pkt 6 upzp]

Pomniki zagłady są zabytkami w rozumieniu ustawy o ochronie zabytków i opiece nad zabytkami. To powtórzenie ustaleń, których należy dokonać na podstawie przepisu art. 15 ust. 2 pkt 4 ustawy o planowaniu i zagospodarowaniu przestrzennym.

\section{Granice terenów zamkniętych, i granice stref ochronnych terenów zamkniętych} zakres fakultatywny [art. 15 ust. 3 pkt 7 upzp]

Ustawa o planowaniu i zagospodarowaniu przestrzennym:

- odsyła do definicji terenów zamkniętych zawartej w ustawie Prawo geodezyjne i kartograficzne (ugk),

- dodatkowo wprowadza pojęcie tereny zamknięte ustalone przez ministra właściwego do spraw transportu [art. 4 ust. 4 upzp].

Tereny zamknięte to „,tereny o charakterze zastrzeżonym ze względu na obronność i bezpieczeństwo państwa, określone przez właściwych ministrów i kierowników urzędów centralnych" [art. 2 pkt 11 upzp w związku z art. 2 pkt 9 ugk].

Co do zasady, nie sporządzania się planów miejscowych dla terenów zamkniętych. Wyjątkiem sa tereny ustalane przez ministra właściwego do spraw transportu [art. 14 ust. 6 upzp]. Skoro plan miejscowy sporządza się dla powyższych terenów, to należy wypełnić wszystkie wymagania wynikające z zakresu stanowienia planu, w szczególności określić ich przeznaczenie.

Relacje między terenami zamkniętymi a planami miejscowymi wymagają innego niż obecnie podejścia. Jak bardzo skomplikowany jest to problem przybliża artykuł Kolej w miejscowym planie zagospodarowania przestrzennego [Wieczorek 2020]. 
Sposób usytuowania obiektów budowlanych w stosunku do dróg i innych terenów publicznie dostępnych oraz do granic przyległych nieruchomości, kolorystyka obiektów budowlanych oraz pokrycie dachów - zakres fakultatywny [art. 15 ust. 3 pkt 8 upzp]

Ustawa o planowaniu i zagospodarowaniu przestrzennym nie określa, czym są obiekty budowlane i nieruchomości. Pojęcia te różnie definiują przepisy odrębne, np. ustawa Prawo budowlane i ustawa o gospodarce nieruchomościami.

Jak już sygnalizowano, nie wiadomo, czym się różnią od siebie:

- przestrzenie publiczne,

- obszar przestrzeni publicznej,

- tereny publicznie dostępne.

Określenie kolorystyki i pokrycia dachów obiektów budowlanych wymaga umieszczenia w planie miejscowym katalogów materiałów budowlanych (tynków, dachówek, blach itp.), bo sam opis często doprowadza do kłopotów z interpretacją ustaleń planu.

Minimalna powierzchnia nowo wydzielonych działek budowlanych - zakres fakultatywny [art. 15 ust. 3 pkt 10 upzp]

Jak już napisano, polski system prawny zawiera określenia: działka budowlana (trzy różne definicje), działka gruntu i działka ewidencyjna.

Zasady wydzielania działek gruntu i działek ewidencyjnych ustalają ustawa o gospodarce nieruchomościami i ustawa Prawo geodezyjne i kartograficzne. Działek budowlanych się nie wydziela - ich granic nie ma na żadnej z map pochodzących z państwowego zasobu geodezyjno-kartograficznego. Działką budowlaną może być jedna działka ewidencyjna, fragment tej działki lub kilka takich działek.

\section{Podsumowanie}

Zakres stanowienia miejscowego planu zagospodarowania przestrzennego jest wieloznaczny i mało precyzyjny, ponieważ:

- zawiera szereg powtórzeń i jest mieszaniną tego, co należy ustalić z wytycznymi i informacjami o uwarunkowaniach, z których ustalenia powinny wynikać,

- w ustawie o planowaniu i zagospodarowaniu przestrzennym i wydanych na jej podstawie przepisach wykonawczych brakuje definicji użytych w nim pojęć oraz jest wiele określeń bliskoznacznych,

- chaos pogłebia niezrozumiały podział na zakres obowiązkowy i zakres fakultatywny.

W zamyśle normodawcy, ustalenia ustawowe uściśla rozporządzenie w sprawie wymaganego zakresu projektu miejscowego planu zagospodarowania, ale to tylko teoria.

Żeby się przekonać, jak bardzo wieloznaczny jest zakres stanowienia planu miejscowego, wystarczy porównać kilka tekstów tych planów. I nie chodzi o różnice wynikające ze specy- 
fiki danego obszaru, ale o sposób rozumienia i definiowania poszczególnych pojęć. Należy wyjaśnić, że sporządzający plan miejscowy ma prawo i obowiązek zdefiniować określenia, które są wieloznaczne, nieostre albo ich znaczenie nie jest powszechnie zrozumiałe. Stanowi o tym § 146 Załącznika do rozporządzenia w sprawie "Zasad techniki prawodawczej” (rozp. ztp). Jeśli w ustawie o planowaniu i zagospodarowaniu przestrzennym użyto pojęcie, które jest niejednoznaczne, to należy je zdefiniować stosując odesłanie do określenia zawartego w przepisach odrębnych [§ 156 Załącznika do rozp. ztp]. Jeżeli w tych przepisach nie ma potrzebnej definicji można:

- powołać normę,

- opracować „własna” definicję, opierając się np. na literaturze przedmiotu czy słownikach.

Zastanowienia wymaga, czy wieloznaczny zakres stanowienia planu miejscowego jest ukłonem ustawodawcy wobec samorządów gmin, czy raczej przekleństwem. Wieloletnie doświadczenie zawodowe autora artykułu wskazuje, że raczej to drugie, zwłaszcza, kiedy organy nadzoru nie szanują władztwa planistycznego gmin z przyczyn pozamerytorycznych.

Przykładowo - za istotne naruszenie prawa może być uznane odesłanie do definicji, której nie aprobuje organ nadzoru. Skutek - stwierdzanie nieważności uchwalonego planu. Autor artykułu zna taki przypadek. Należy wyjaśnić, że rozporządzenie w sprawie „Zasad techniki prawodawczej” nie przesądza do jakiego przepisu odrębnego należy zastosować odesłanie, kiedy dwa przepisy definiują różnie to samo pojęcie. Nie wolno jedynie stosować odesłania do określenia bliskoznacznego. „Do oznaczenia jednakowych pojęć używa się jednakowych określeń, a różnych pojęć nie oznacza się tymi samymi określeniami." [§ 10 Załącznika do rozp. ztp].

Brak jednoznaczności planów miejscowych utrudnia porównywanie ich ustaleń. Skarżą się na to osoby szukające optymalnej lokalizacji pod różnego rodzaju inwestycje.

Analiza przepisów art. 15 ustawy o planowaniu i zagospodarowaniu przestrzennym wskazuje, że zakres planu miejscowego można sprowadzić do trzech podstawowych punktów:

- przeznaczenie terenów,

- zagospodarowanie terenów,

- $\quad$ stawki procentowe, na podstawie których ustala się opłatę, naliczaną od wzrostu wartości nieruchomości, która nastąpiła na skutek uchwalenia planu miejscowego.

Wydaje się, że przeznaczenie terenu/ów oznacza zbiór elementów, które moga istnieć i powstać na danym terenie, takich jak: zabudowa, zieleń (roślinność) i wody. Ta ogólna definicja wymaga uściślenia. Kluczowym będzie określenie pojęcia zabudowa.

Dla definiowania wód naturalnym wydaje się odesłanie do ustawy Prawo wodne.

Rośliny i ich zespoły powinno się określać w podstawowym podziale na:

- roślinność występującą w lasach,

- roślinność związaną z rolnictwem,

- inną roślinność, np. towarzyszącą obiektom budowlanym. 
Należałoby również wskazać czy dany teren jest przeznaczony wyłącznie na cele publiczne, czy nie ma znaczenia jaki rodzaj inwestycji na nim powstanie.

Wydaje się, że pod pojęciem zagospodarowanie terenów należy przede wszystkim rozumieć:

- parametry zabudowy, w szczególności jej wysokości i zajęte przez nią powierzchnie,

- relacje pomiędzy terenami zajętymi przez zabudowę a terenami pokrytymi roślinnością i wodami (powierzchnia biologicznie czynna),

- sposób sytuowania względem siebie poszczególnych elementów, składających się na przeznaczenie terenu,

- parametry działek.

Przeznaczenie terenu/ów i ich zagospodarowanie będzie zależało od szeregu czynników, w szczególności od:

- stanu istniejącego na obszarze objętym planem miejscowym,

- potrzeb mieszkańców tego obszaru oraz właścicieli nieruchomości,

- inwestycji niezbędnych z punktu widzenia całej gminy, powiatu, województwa czy kraju (inwestycji celu publicznego),

- $\quad$ wytycznych i informacji zawartych w przepisach odrębnych.

Przepisy odrębne nie zawsze są ze sobą spójne:

- zawierają różne ustalenia dla tych samych terenów, np. krajobrazu,

- różnie definiuja te same pojęcia, co powoduje, że nie wiadomo, do którego przepisu zastosować odesłanie,

- stosują określenia bliskoznaczne do pojęć użytych w ustawie o planowaniu i zagospodarowaniu przestrzennym, wprowadzając niepewność, czy odnoszą się do tych samych zagadnień.

Byłoby wskazane, żeby:

- te same pojęcia używane w różnych aktach prawa miały te same definicje,

- ustalenia dotyczące tych samych terenów, a zawarte w różnych przepisach odrębnych nie kolidowały ze soba, np.: formy ochrony zabytków z formami ochrony przyrody.

Będzie to z pożytkiem nie tylko dla planów miejscowych, ale również dla innych dziedzin naszego życia.

Wyjątkowo mało precyzyjna definicja ładu przestrzennego nie ułatwia a utrudnia zachowanie tego ładu w przestrzeni - lepiej usunąć to pojęcie z naszego systemu prawnego.

\section{Materiały źródłowe}

\section{Literatura}

Niewiadomski Z. (red.), 2019, Planowanie i zagospodarowanie przestrzenne. Komentarz, wydanie 11, Seria: Komentarze Becka, Warszawa. 
Nowak M.J., 2019, Planowanie i zagospodarowanie przestrzenne. Komentarz do ustawy i przepisów powiazanych, Wydawnictwo Beck, Warszawa.

Stelmach-Fita B., Wieczorek A., 2019, Problemy z ocenianiem zgodności z prawem miejscowych planów zagospodarowania przestrzennego: definicje pojęć powierzchnia zabudowy i powierzchnia catkowitej zabudowy, Metropolitan. Przegląd Naukowy, 1, 11, Półrocznik publikowany w formie cyfrowej ISSN 2353-7558, s. 50-59.

Wieczorek A., 2020, Kolej w miejscowym planie zagospodarowania przestrzennego, MAZOWSZE Studia Regionalne, 32, Mazowieckie Biuro Planowania Regionalnego, Warszawa, s. 99-122.

\section{Źródła prawa}

Konstytucja Rzeczypospolitej Polskiej z dnia 2 kwietnia 1997 r. (Dz.U. nr 78, poz. 483 z późn. zm.).

\section{Ustawy:}

Ustawa z dnia 26 marca 1982 r. o scalaniu i wymianie gruntów (tj. z dnia 13 kwietnia 2018 r. Dz.U. z 2018 r. poz. 908 z późn. zm.).

Ustawa z dnia 17 maja 1989 r. Prawo geodezyjne i kartograficzne (tj. z dnia 8 października 2020 r. Dz.U. z 2020 r. poz. 2052 z późn. zm.), w skrócie ugk.

Ustawa z dnia 8 marca 1990 r. o samorządzie gminnym (tj. z dnia 25 czerwca 2021 r. Dz.U. z 2021 r. poz. 1372), w skrócie usg.

Ustawa z dnia 7 lipca 1994 r. Prawo budowlane (tj. z dnia 7 lipca 2020 r. Dz.U. z 2020 r. poz. 1333 z późn. zm.), w skrócie uPb.

Ustawa z dnia 21 sierpnia 1997 r. o gospodarce nieruchomościami (tj. z dnia 21 października 2020 r. Dz.U. z 2020 r. poz. 1990 z późn. zm.), w skrócie ugn.

Ustawa z dnia 5 czerwca 1998 r. o samorządzie województwa (tj. z dnia 16 września 2020 r. Dz.U. z 2020 r. poz. 1668 z późn. zm.), w skrócie usw.

Ustawa z dnia 27 kwietnia 2001 r. Prawo ochrony środowiska (tj. z dnia 29 maja 2020 r. Dz.U. z 2020 r. poz. 1219 z późn. zm.), w skrócie Poś.

Ustawa z dnia 27 marca 2003 r. o planowaniu i zagospodarowaniu przestrzennym (tj. z dnia 31 marca 2021 r. Dz.U. z 2021 r. poz. 741 z późn. zm.), w skrócie upup.

Ustawa z dnia 23 lipca 2003 r. o ochronie zabytków i opiece nad zabytkami (tj. z dnia 19 marca 2021 r. Dz.U. z 2021 r. poz. 710 z późn. zm.), w skrócie uoz. 
Ustawa z dnia 16 kwietnia 2004 r. o ochronie przyrody (tj. z dnia 18 maja 2021 r. Dz.U. z 2021 r. poz. 1098), w skrócie uop.

Ustawa z dnia 6 grudnia 2006 r. o zasadach prowadzenia polityki rozwoju (tj. z dnia 21 maja 2021 r. Dz.U. z 2021 r. poz. 1057), w skrócie uzppr.

Ustawa z dnia 9 czerwca 2011 r. Prawo geologiczne i górnicze (tj. z dnia 2 lipca 2021 r. Dz.U. z 2021 r. poz. 1420 z późn. zm.), w skrócie uPg.

Ustawa z dnia 24 kwietnia 2015 r. o zmianie niektórych ustaw w związku ze wzmocnieniem narzędzi ochrony krajobrazu (Dz.U. z 2015 r. poz. 774).

Ustawa z dnia 20 lipca 2017 r. Prawo wodne (tj. z dnia 1 marca 2021 r. Dz.U. z 2021 r. poz. 624 z późn. zm.).

Ustawa z dnia 5 lipca 2018 r. o ułatwieniach w przygotowaniu i realizacji inwestycji mieszkaniowych oraz inwestycji towarzyszących (tj. z dnia 21 lipca 2021 r. Dz.U. z 2021 r. poz. 1538 z późn. zm.), w skrócie uuim.

\section{Rozporządzenia:}

Rozporządzenie Ministra Infrastruktury z dnia 12 kwietnia 2002 r. w sprawie warunków technicznych jakim powinny odpowiadać budynki i ich usytuowanie (tj. z 8 kwietnia $2019 \mathrm{r}$. Dz.U. z 2019 r. poz. 1065 z późn. zm.), w skrócie rozp.w.t.

Rozporządzenie Prezesa Rady Ministrów z dnia 20 czerwca 2002 r. w sprawie „Zasad techniki prawodawczej" (tj. z dnia 29 lutego 2016 r. Dz.U. z 2016 r. poz. 283) w skrócie rozp.ztp.

Rozporządzenie Ministra Infrastruktury z dnia 26 sierpnia 2003 r. w sprawie wymaganego zakresu projektu miejscowego planu zagospodarowania przestrzennego (Dz.U. nr 164 z 2003 r. poz. 1587), w skrócie rozp. mpzp.

Rozporządzenie Ministra Rozwoju, Pracy i Technologii z dnia 27 lipca 2021 r. w sprawie ewidencji gruntów i budynków (Dz.U. z 2021 r. poz. 1390), w skrócie rozp. eg.

\section{Dokumenty}

Ministerstwo Rozwoju - dokument pt. „Założenia reformy systemu planowania i zagospodarowania przestrzennego" z $2020 \mathrm{r}$. 


\section{Imposing spatial order - an efficient system or chaos? Local spatial development plan - the scope of regulation}

\section{ABSTRACT}

The law is one of the factors that significantly affect the quality of space. This paper is another in a series of articles on the spatial planning system in Poland and the first of three on the scope of constituting local spatial development plans. In a general way it refers to the entire scope. The next two articles entitled:

- "Imposing spatial order - an efficient system or chaos? Local spatial development plan - land use"

- $\quad$ "Imposing spatial order - an efficient system or chaos? Local spatial development plan - development parameters" refer in detail to the key issues in this field.

In order to maintain the precision of the statement, a number of quotations have been used.

The local spatial development plan, a key act of local law for shaping the space, has an ambiguous and imprecise scope of regulation, because:

- it contains a number of repetitions and is a "mixture" of what should be established with the guidelines and information on the conditions, from which the findings should result;

- in the Act on spatial planning and land use management and executive regulations issued on its basis there is a lack of definitions of the terms used in it and there are many synonymous terms;

- the chaos is deepened by the incomprehensible division into the obligatory and the optional scope. All this hinders drawing up of local plans, and thus adversely affects the quality of space and leads to unnecessary disputes, including court ones, which could be avoided if the law was precise.

Key words: local spatial development plan, the scope of regulation, land use, land development

Anna Wieczorek - na Politechnice Warszawskiej ukończyła Wydział Architektury, Podyplomowe Studium Urbanistyki, Studium Doskonalenia Pedagogicznego oraz uzyskała dyplom doktora nauk technicznych. Posiada uprawnienia do projektowania w planowaniu przestrzennym oraz uprawnienia do pełnienia samodzielnych funkcji technicznych w budownictwie. Specjalizuje się w wykonywaniu projektów miejscowych planów zagospodarowania przestrzennego (główny projektant ponad 30 uchwalonych projektów planów miejscowych) oraz projektów studiów uwarunkowań i kierunków zagospodarowania przestrzennego gmin (główny projektant 5 uchwalonych studiów). Ma doświadczenie w pracy ze studentami - na Politechnice Warszawskiej i w Wyższej Szkole Przedsiębiorczości i Administracji w Lublinie. Należy do Mazowieckiej Okręgowej Izby Architektów z siedzibq̨ w Warszawie oraz Pan-Europejskiej Federacji Ochrony Zabytków - Europa Nostra z siedzibq w Holandii.

Anna Wieczorek - graduate of the Warsaw University of Technology - Faculty of Architecture, Postgraduate Town Planning Studies, Pedagogical study, PhD in technical science. Holds professional permits for spatial planning and is authorised to perform independent technical functions in construction. Specialises in the preparation of local spatial development plans (is the main designer of more than 30 approved local development plans) and draft studies of conditions and directions of the spatial development of municipalities (main designer of 5 approved studies). Has experience in working with students - at the Warsaw University of Technology and the University College of Enterprise and Administration in Lublin. Member of the Warsaw-based Masovian Chamber of Architects and the Pan-European Federation for Cultural Heritage, Europa Nostra based in the Netherlands. 